\title{
Metabolism of $\mathrm{C}_{19}$-Steroids by Homogenates of Normal Rat and Mouse Adrenal Tissue and of the Snell Transplantable Rat Adrenocortical Tumour 494
}

\author{
By P. V. MAYNARD and E. H. D. CAMERON \\ Tenovus Institute for Cancer Research, Welsh National School of Medicine, Heath, \\ Cardiff CF 4 4XX, U.K.
}

(Received 23 June 1971)

\begin{abstract}
$\mathrm{C}_{19}$-steroid metabolism in homogenates of adrenal tissue from rats and mice has been studied. Production of these compounds from $\left[7 \alpha_{-}^{3} \mathrm{H}\right]$ cholesterol by rat adrenal tissue appeared to follow a route independent of pregnenolone. The major products of $\left[7 \alpha^{3} \mathrm{H}\right]-$ dehydroepiandrosterone metabolism by rat adrenal tissue were $5 \alpha$-reduced steroids, principally androsterone, epiandrosterone and $5 \alpha$-androstanedione. No differences in metabolism of $\left[7 \alpha-{ }^{3} \mathrm{H}\right]$ dehydroepiandrosterone or $\left[4-{ }^{14} \mathrm{C}\right]$ pregnenolone were detected between adrenal tissue from Sprague-Dawley, Wistar and Osborne-Mendel rats, but experiments with the Snell rat adrenocortical tumour 494 showed that this tissue had low $5 \alpha$-reductase activity. In contrast, the major products of $\left[7 \alpha^{3} \mathrm{H}\right]$ dehydroepiandrosterone metabolism by mouse adrenal tissue were $5 \beta$-reduced steroids. Differences were observed between LACA and NH strains of mice in that there was a lower metabolism of androstenedione by $\mathrm{NH}$ mouse adrenal and a considerable difference in the proportions of aetiocholanolone and epiaetiocholanolone produced.
\end{abstract}

In this paper the following trivial names are used: adrenosterone, androst-4-ene-3,11,17-trione; aetiocholanolone, $3 \alpha$-hydroxy-5 $\beta$-androstan-17-one; $5 \alpha$ androstanedione, $5 \alpha$-androstane-3,17-dione; $5 \beta$ androstanedione, $5 \beta$-androstane-3,17-dione; androstenedione, androst-4-ene-3,17-dione; androsterone, $3 \alpha$-hydroxy- $5 \alpha$-androstan-17-one; cholesterol, cholest-5-en-3 $\beta$-ol; corticosterone, 11 $\beta, 21$-dihydroxypregn-4-ene-3,20-dione; dehydroepiandrosterone, $3 \beta$ hydroxyandrost-5-en-17-one; $5 \alpha$-dihydrotestosterone, $17 \beta$-hydroxy-5 $\alpha$-androstan-3-one; $5 \beta$-dihydrotestosterone, $17 \beta$-hydroxy- $5 \beta$-androstan-3-one; deoxycorticosterone, 21-hydroxypregn-4-ene-3,20-dione; epiaetiocholanolone, $3 \beta$-hydroxy- $5 \beta$-androstan17-one; testosterone, 17 $\beta$-hydroxyandrost-4-en-3one; pregnenolone, $3 \beta$-hydroxypregn-5-en-20-one; progesterone, pregn-4-ene-3,20-dione.

In Osborne-Mendel rats adrenocortical tumours arise spontaneously in old animals, and one such tumour occurring in a female animal of this strain has been maintained as a transplantable line (Snell \& Stewart, 1959). Similar neoplasms develop in ageing female NH mice (Kirschbaum et al., 1946).

The biosynthetic pathways by which $\mathrm{C}_{19}$-steroids can be produced in rat adrenal tissue have been reported to follow a route through pregnenolone to dehydroepiandrosterone (Favino et al., 1966), or directly from cholesterol to dehydroepiandrosterone (Jungmann, 1968). Recently, however, doubt has been cast on the existence of the 'direct' pathway, because
Burstein et al. (1971) were unable to demonstrate $\left[25,26-{ }^{3} \mathrm{H}_{2}\right]$ cholesterol cleavage in such a manner as to give rise to significant quantities of a ${ }^{3} \mathrm{H}$-labelled $\mathrm{C}_{8}$-fragment.

However, the metabolism of $\mathrm{C}_{19}$-steroids in the rodent adrenal gland has not been investigated in any depth and a study of this in Sprague-Dawley rats and LACA mice was undertaken. A comparison was also made of the steroid-metabolizing enzymes in adrenal tissue from Sprague-Dawley and Wistar rats with that from Osborne-Mendel rats and the Snell transplantable tumour 494. A similar comparison was made between adrenal tissue from female LACA and NH mice. Such studies were designed to reveal any differences between 'normal' strains and those with a suspected general endocrine imbalance.

\section{Materials and Methods}

\section{Materials}

Animals. Rats of the Sprague-Dawley, Wistar and Osborne-Mendel strains, and mice of the NH strain were bred and maintained conventionally. LACA mice were purchased from Fisons Pharmaceutical, Loughborough, Leics., U.K.

The Snell adrenocortical tumour 494 (Snell \& Stewart, 1959), generously supplied by Dr. Katharine C. Snell, was maintained in male Osborne-Mendel rats. 
Reagents. All reagents including ethanol and methanol were of analytical grade. Other solvents were of laboratory-reagent grade and were redistilled before use.

Radioactive substrates. $\left[7 \alpha_{-}{ }^{3} \mathrm{H}\right]$ Cholesterol (specific radioactivity $\quad 7.35 \mathrm{Ci} / \mathrm{mmol}), \quad\left[7 \alpha_{-}{ }^{3} \mathrm{H}\right]$ dehydroepiandrosterone (specific radioactivity $500 \mathrm{mCi} / \mathrm{mmol}$ ), $\left[7 \alpha^{-3} \mathrm{H}\right]$ pregnenolone (specific radioactivity $6.9 \mathrm{Ci} /$ $\mathrm{mmol}$ ) and $\left[4-{ }^{14} \mathrm{C}\right]$ pregnenolone (specific radioactivity $55.7 \mathrm{mCi} / \mathrm{mmol}$ ) were obtained from The Radiochemical Centre, Amersham, Bucks., U.K. The purity of these materials was checked by reverse isotope dilution with chromatography on thin layers of silica gel in a number of solvent systems before and after derivative formation.

\section{Methods}

Incubation procedure. Animals were killed by cervical dislocation and the adrenal glands or tumour removed and placed in a Petri dish on ice. The tissues were freed from fat (and decapsulated in the case of normal, non-tumorous, rat tissue) and a $20 \%$ homogenate prepared in $0.25 \mathrm{M}$-sucrose containing $0.12 \mathrm{M}$ nicotinamide. This was mixed with an equal volume of an incubation medium (Griffiths \& Glick, 1966) containing cofactors such that the final concentration of each was: tris- $\mathrm{HCl}$ buffer, $\mathrm{pH} 7.4,43.02 \mathrm{~mm} ; \mathrm{KCl}$, $42.82 \mathrm{mM} ; \mathrm{MgSO}_{4}, 3.16 \mathrm{mM}$; potassium fumarate, $8.57 \mathrm{~mm}$; ATP, $0.94 \mathrm{~mm}$; $\mathrm{NADP}^{+}, 0.18 \mathrm{~mm}$; glucose 6-phosphate, $17.60 \mathrm{~mm}$; glucose 6-phosphate dehydrogenase, 0.5 Kornberg unit (Kornberg \& Horecker, 1955)/ml.

A solution of the required radioactive precursor in benzene was placed in an incubation flask, together with propylene glycol $(0.1 \mathrm{ml})$. After the benzene had been evaporated in a stream of air the adrenal preparation was added. Incubations were performed in a shaking water bath at $37^{\circ} \mathrm{C}$ in an atmosphere of air and were normally terminated by the addition of acetone $(15 \mathrm{ml})$ containing $500 \mu \mathrm{g}$ of each carrier steroid.

Extraction and fractionation of steroids. Incubation mixtures containing acetone and carrier steroids were homogenized in a Silverson mixer and filtered. Residues were then washed three times with $30 \mathrm{ml}$ volumes of acetone and the pooled extract and washings evaporated almost to dryness under reduced pressure. These extracts were partitioned between light petroleum (b.p. $\left.80-100^{\circ} \mathrm{C}\right)(20 \mathrm{ml})$ and aq. $80 \%(\mathrm{v} / \mathrm{v})$ methanol $(3 \times 20 \mathrm{ml})$. The aqueous methanol fractions were combined and the methanol was evaporated under reduced pressure. This aqueous residue was then diluted to $20 \mathrm{ml}$ with water and extracted with diethyl ether $(3 \times 20 \mathrm{ml})$. After evaporation of the ether the steroid fraction remaining was subjected to extensive paper and thin-layer chromatography as described below.

Derivative formation, chromatography and measure- ment of steroids. Derivatives were prepared by the methods described by Griffiths et al. (1963), except that acetates of $\mathrm{C}_{19}$-steroids were hydrolysed by addition of $0.1 \mathrm{M}-\mathrm{KOH}$ in aq. $70 \%$ (v/v) methanol $(0.4 \mathrm{ml})$ to the steroid residue dissolved in methanol $(0.2 \mathrm{ml})$ (Pierrepoint et al., 1969). The mixture was kept overnight at room temperature and the steroid material was extracted with ethyl acetate $(2 \times 5 \mathrm{ml})$ after the addition of water $(2 \mathrm{ml})$.

Paper chromatography was performed on Whatman no. 1 paper in the descending system methanolwater - light petroleum (b.p. $80-100^{\circ} \mathrm{C}$ ) - benzene (70:30:67:33, by vol.; solvent PB21) or methanolwater - light petroleum (b.p. $\left.80-100^{\circ} \mathrm{C}\right)(9: 1: 10$, by vol.; solvent P10-M) (Griffiths et al., 1963).

The procedures used for the identification of steroids and the establishment of their radiochemical purity involved extensive t.l.c. on Merck silica gel $\mathrm{HF}_{254 / 366}$ in at least three systems that were selected from the following, the solvent proportions being by volume: (I) cyclohexane - ethyl acetate (1:1); (II) cyclohexane-ethyl acetate (7:3); (III) cyclohexaneethyl acetate (4:1); (IV) chloroform-acetone (37:3); (V) chloroform-ethanol (19:1); (VI) diethyl etherethyl acetate (19:1); (VII) hexane-chloroform acetone - diethyl ether (140:10:1:50); (VIII) cyclohexane-acetone-chloroform (10:3:3);(IX)(n-)butyl acetate; (X) benzene-ethyl acetate $(9: 1)$; (XI) chloroform-methanol-water $(187: 12: 1)$.

G.1.c. was employed for the determination of $\Delta^{5}$-3 $\beta$-hydroxy steroids and ring-A-reduced steroids. The technique involved the use of a Pye 104 gas chromatograph with flame ionization detector (model 24) with internal standardization on a $3 \%$ $\mathrm{OV}-1$ column $152 \mathrm{~cm}$ in length. The mass of $\Delta^{4}-3-$ oxo steroids was measured by means of their selective absorption at $240 \mathrm{~nm}$. Radioactivity was measured in a Nuclear-Chicago Mk II liquid-scintillation spectrometer. A portion of the steroid sample in ethanol solution was placed in a counting vial and the solvent was evaporated. The residue was then dissolved in toluene $(5 \mathrm{ml})$ containing $0.3 \% 2,5-$ diphenyloxazole and $0.01 \%$ 1,4-bis-(4-methyl-5phenyloxazol-2-yl)benzene. The counting efficiency was $45 \%$ for ${ }^{3} \mathrm{H}$ and $90 \%$ for ${ }^{14} \mathrm{C}$ in samples containing a single radioactive isotope. In samples containing both radioactive isotopes the efficiency was $40 \%$ for ${ }^{3} \mathrm{H}$ and $55 \%$ for ${ }^{14} \mathrm{C}$ in their respective channels. No spill-over of ${ }^{3} \mathrm{H}$ was observed in the ${ }^{14} \mathrm{C}$ channel and ${ }^{14} \mathrm{C}$ was counted with an efficiency of $18 \%$ in the ${ }^{3} \mathrm{H}$ channel. D.p.m. for each isotope were then calculated by the method of Okita et al. (1957). The observation that the specific radioactivities of a steroid and two of its derivatives differed by not more than $10 \%$ was taken as satisfactory evidence for radiochemical purity. The mean of the specific radioactivities was used to calculate the percentage conversion from the original steroid precursor. 


\section{Results}

To demonstrate that rat adrenal tissue has the ability to produce $\mathrm{C}_{19}$-steroids from cholesterol or pregnenolone under the standard conditions used throughout this investigation, an incubation was performed with a homogenate preparation by using $\left[7 \alpha-{ }^{3} \mathrm{H}\right]$ cholesterol and $\left[4-{ }^{14} \mathrm{C}\right]$ pregnenolone as substrates. As can be seen from Table 1 small amounts of ${ }^{3} \mathrm{H}$ were found in some of the androgens isolated, but in no case was any ${ }^{14} \mathrm{C}$ detected. Thus under the conditions employed, cholesterol was apparently metabolized to the $\mathrm{C}_{19}$-steroids examined without formation of pregnenolone as an intermediate.

Although the evidence so described does not establish the existence of a direct route from cholesterol to dehydroepiandrosterone, incubation of $\left[7 \alpha-{ }^{3} \mathrm{H}\right] \mathrm{dehydroepiandrosterone}$ with SpragueDawley rat adrenal tissue was undertaken to establish the identity of the $\mathrm{C}_{19}$-steroid metabolites produced by such a preparation. Because the identity of the products was not known in this preliminary experiment, no carrier steroids were added at the end of the incubation period. The neutral steroids in the ether fraction were subjected to paper chromatography in system PB21 (3.5h), after which three radioactive regions were detected on scanning.

The least polar zone $\left(\boldsymbol{R}_{\boldsymbol{F}} \mathbf{0 . 6 - 1 . 0 )}\right.$ was eluted and chromatographed in system P10-M, which was overrun for $7.5 \mathrm{~h}$, when a further three distinct radioactive zones were found. These were characterized as $5 \alpha$-androstanedione, androsterone and epiandrosterone by comparison of their chromatographic mobilities with authentic compounds before and after derivative formation.

The mid-polar zone $\left(R_{F}\right.$ 0.4-0.6) was eluted and, after acetylation, re-run in the PB21 system $(3.5 \mathrm{~h})$ whereupon two radioactive zones were detected. The acetylated material had chromatographic mobilities identical with those of the acetates of testosterone, $5 \alpha$-androstane-3 $3,17 \beta$-diol and $5 \alpha$-androstane$3 \beta, 17 \beta$-diol. These were again further characterized after derivative formation. The non-acetylated material was tentatively identified as $11 \beta$-hydroxy$5 \alpha$-androstanedione, but lack of the authentic compound prevented complete characterization.

The most polar zone of the initial chromatogram $\left(R_{F} 0.0-0.4\right)$ was eluted and then over-run in the PB21

Table 1. Conversion of $10 \mu \mathrm{Ci}$ of $\left[7 \alpha^{3} \mathrm{H}\right]$ cholesterol and $2 \mu \mathrm{Ci}$ of $\left[4-{ }^{14} \mathrm{C}\right]$ pregnenolone simultaneously into various metabolites by a homogenate of $200 \mathrm{mg}$ of adrenal tissue from Sprague-Dawley rats, incubated for $2 \mathrm{~h}$

A zero indicates that radioactivity was not significantly above background.

Steroid investigated and derivative formed

Pregnenolone

$20 \beta$-Hydroxypregnenolone

$20 \beta$-Acetoxypregnenolone

Androstenedione

Testosterone

Testosterone acetate

$11 \beta$-Hydroxyandrostenedione

$11 \beta$-Hydroxytestosterone

Adrenosterone

$5 \alpha$-Androstanedione

$5 \alpha$-Androstane-3 $\beta, 17 \beta$-diol

$5 \alpha$-Androstane-3 $\beta, 17 \beta$-diol diacetate

Dehydroepiandrosterone

Androst-5-ene-3 $\beta, 17 \beta$-diol

Dehydroepiandrosterone acetate

Androsterone

$5 \alpha$-Androstanedione

$5 \alpha$-Androstane- $3 \beta, 17 \beta$-diol

Epiandrosterone

$5 \alpha$-Androstanedione

$5 \alpha$-Androstane-3 $\beta, 17 \beta$-diol
Final

solvent

system

IV

IV

$\mathrm{X}$

I

IV

I

IV

V

IV

II

VI

III

I

IV

VII

I

VII

II

I

VII

II
Specific radioactivities (d.p.m./nmol)

$\begin{array}{rr}{ }^{3} \mathrm{H} & { }^{14} \mathrm{C} \\ 376 & 155 \\ 343 & 158 \\ 339 & 162 \\ 51.3 & 0 \\ 51.7 & 0 \\ 53.9 & 0 \\ 11.7 & 0 \\ 11.4 & 0 \\ 10.8 & 0 \\ 6.8 & 0 \\ 7.1 & 0 \\ 6.9 & 0 \\ 0.7 & 0 \\ 0.6 & 0 \\ 0.6 & 0 \\ 0.5 & 0 \\ 0.6 & 0 \\ 0.7 & 0 \\ 0.4 & 0 \\ 0.5 & 0 \\ 0.5 & 0\end{array}$

$\%$ of radioactivity

found in isolated steroids

$\overbrace{}^{3} \mathrm{H}{ }^{14} \mathrm{C}$

1.93

0.32

0.07

0.04

Trace

Trace

0

Trace
5.03

0

0

0

0

${ }^{14} \mathrm{C}$

0

Vol. 126 
system for $7.5 \mathrm{~h}$, after which four radioactive zones were detected. Three of these were characterized as $11 \beta$-hydroxyandrost-4-ene-dione, $11 \beta$-hydroxyandrosterone and $11 \beta$-hydroxyepiandrosterone. The most polar region could not be properly identified, but was not an androstane-3,11,17-triol. No $5 \beta$ reduced compounds could be detected in the incubation extract.
The above experiment was then repeated but, at the end of the incubation period, $500 \mu \mathrm{g}$ of the steroids identified as metabolites of $\left[7 \alpha^{-}{ }^{3} \mathrm{H}\right]$ dehydroepiandrosterone were added, thus enabling the conversion into these compounds to be accurately determined (Table 2). Incubation of tissue from the Snell adrenocortical carcinoma 494 with $\left[7 \alpha^{3} \mathrm{H}\right]-$ dehydroepiandrosterone showed a complete contrast

Table 2. Conversion of $10 \mu \mathrm{Ci}$ of $\left[7 \alpha_{-}^{3} \mathrm{H}\right]$ dehydroepiandrosterone into various metabolites by homogenates of $150 \mathrm{mg}$ of tissue of adrenal glands from 4-month-old Sprague-Dawley rats and from Snell adrenocortical carcinoma 494 incubated for $90 \mathrm{~min}$

- indicates that the steroid was not examined.

Steroid investigated and derivative formed

Dehydroepiandrosterone Androst-5-ene-3 $\beta, 17 \beta$-diol

Dehydroepiandrosterone acetate

Androstenedione

Testosterone

Testosterone acetate

Testosterone

Androstenedione

Testosterone acetate

$5 \alpha$-Androstanedione

$5 \alpha$-Androstane- $3 \beta, 17 \beta$-diol

$5 \alpha$-Androstane-3 $\beta, 17 \beta$-diol diacetate

Androsterone

Androsterone acetate

$5 \alpha$-Androstanedione

Epiandrosterone

Epiandrosterone acetate

$5 \alpha$-Androstanedione

$5 \alpha$-Androstane- $3 \alpha, 17 \beta$-diol

$5 \alpha$-Androstanedione

$5 \alpha$-Androstane- $3 \beta, 17 \beta$-diol

$5 \alpha$-Androstane- $3 \beta$-17 $\beta$-diol

$5 \alpha$-Androstanedione

$5 \alpha$-Androstane- $3 \beta, 17 \beta$-diol diacetate

$11 \beta$-Hydroxyandrostenedione

$11 \beta$-Hydroxytestosterone

Adrenosterone

$11 \beta$-Hydroxyandrosterone

$11 \beta$-Hydroxyandrosterone acetate

$5 \alpha$-Androstane-3,11,17-trione

$11 \beta$-Hydroxyepiandrosterone

$11 \beta$-Hydroxyepiandrosterone acetate

$5 \alpha$-Androstane-3,11,17-trione
Specific

radioactivities

(d.p.m./nmol)

\begin{tabular}{|c|c|}
\hline $\begin{array}{c}\text { Final } \\
\text { solvent } \\
\text { system }\end{array}$ & $\begin{array}{l}\text { Rat adrenal } \\
\text { tissue }\end{array}$ \\
\hline I & 93.2 \\
\hline IV & 101.6 \\
\hline VII & 94.2 \\
\hline I & 15.4 \\
\hline IV & 13.9 \\
\hline I & 14.0 \\
\hline IV & 4.1 \\
\hline I & 4.2 \\
\hline I & 3.9 \\
\hline II & 1255 \\
\hline VI & 1283 \\
\hline III & 1374 \\
\hline I & 2467 \\
\hline VII & 2571 \\
\hline II & 2534 \\
\hline I & 3594 \\
\hline VII & 3523 \\
\hline II & 3822 \\
\hline VI & 396 \\
\hline II & 382 \\
\hline VI & 366 \\
\hline VI & 750 \\
\hline II & 790 \\
\hline III & 821 \\
\hline IV & 616 \\
\hline V & 609 \\
\hline IV & 574 \\
\hline V & 94.1 \\
\hline IV & 88.4 \\
\hline VIII & 92.6 \\
\hline V & 352 \\
\hline IV & 378 \\
\hline VIII & 361 \\
\hline
\end{tabular}

$\%$ of radioactivity

found in isolated steroids

$\overbrace{\begin{array}{c}\text { Rat adrenal } \\ \text { tissue }\end{array}}^{\begin{array}{c}\text { Snell } \\ \text { carcinoma } \\ 494\end{array}}$

$0.8 \quad 3.74$

0.1

68.0

10453
9861

$\left.\begin{array}{c}- \\ 520 \\ 499 \\ 539 \\ 644 \\ 614 \\ 632 \\ 2289 \\ 2200 \\ 2121 \\ -\end{array}\right\}$

0.03

11.1

3.6

21.9

4.3

30.9

15.1

3.2

6.7

36.7

36.1

38.6

5.1

0.3

0.74

2.9 
in the proportions of the metabolites produced, the radioactivity being largely associated with androstenedione (Table 2).

A series of incubations with adrenal tissue from rats aged approximately 4 months and 15 months of both sexes of the Sprague-Dawley, Wistar and Osborne-Mendel strains showed no significant differences from one another in the metabolism of $\left[7 \alpha^{-3} \mathrm{H}\right]$ dehydroepiandrosterone. $\left[4-{ }^{14} \mathrm{C}\right]$ Pregnenolone was incubated simultaneously with the $\left[7 \alpha_{-}{ }^{3} \mathrm{H}\right]-$ dehydroepiandrosterone in this series of experiments and again no marked differences between the strains, ages or sexes were observed.

When tissue from the tumour 494 was incubated with $\left[7 \alpha-{ }^{3} \mathrm{H}\right]$ pregnenolone a different pattern of metabolism was observed (Table 3). Approximately half of the substrate remained unchanged and most of the remainder was associated with deoxycorticosterone. By comparison, in an incubation of adrenal tissue from 4-month-old Sprague-Dawley rats, little substrate, progesterone or deoxycorticosterone was left $(1 \%)$ and $50.7 \%$ of the radioactivity was associated with corticosterone (Table 3).

Identification of the metabolites of $\left[7 \alpha^{3} \mathrm{H}\right]-$ dehydroepiandrosterone produced by adrenal tissue from female LACA mice was performed in a manner similar to that described for the rat. Paper chromatography of the neutral steroids in the PB21 system (3.5h) showed a similar tripartite distribution of radioactivity but on thin-layer chromatography in system IV most of the material of the least polar zone was found to be associated with aetiocholanolone. The other androstanolones were detected after acetylation and t.l.c. in system VII and hydrolysis and rechromatography in system IV.

The acylable components of the mid-polar zone contained testosterone, $5 \alpha$-androstane-3 $\alpha, 17 \beta$-diol and $5 \alpha$-androstane-3 $\beta, 17 \beta$-diol. Non-acylatable material after oxidation was chromatographed in system VIII, after which two further regions of radioactivity were detected. These were associated with $5 \alpha$-androstane-3,11,17-trione and $5 \beta$-androstane3,11,17-trione and it was concluded that the incubation had contained steroids that were probably $11 \beta$-hydroxy- $5 \alpha$-androstanedione and $11 \beta$-hydroxy$5 \beta$-androstanedione. The most polar zone contained $11 \beta$-hydroxyandrostenedione in addition to small quantities of $11 \beta$-hydroxyaetiocholanolone, $11 \beta$ hydroxyandrosterone and $11 \beta$-hydroxyepiandrosterone.

Again, the above experiment was repeated, $500 \mu \mathrm{g}$ of each steroid identified above being added as carrier compounds at the end of the incubation period. The conversion of $\left[7 \alpha_{-}{ }^{3} \mathrm{H}\right]$ dehydroepiandrosterone into these compounds was thus estimated (Table 4) and, in contrast with the rat adrenal incubation in which only $5 \alpha$-reduced steroids were found, $5 \alpha$ - and $5 \beta$-isomers were present although the major proportion was of the $5 \beta$-series. The results of one incubation with adrenal tissue from female NH mice (Table 4) revealed differences in the proportions of $\left[7 \alpha^{3} \mathrm{H}\right]$ dehydroepiandrosterone

Table 3. Conversion into various metabolites of $2 \mu \mathrm{Ci}$ of $\left[4-{ }^{14} \mathrm{C}\right]$ pregnenolone by a homogenate of $150 \mathrm{mg}$ of adrenal tissue from 4-month-old Sprague-Dawley rats and of $10 \mu \mathrm{Ci}$ of $\left[7 \alpha_{-}^{3} \mathrm{H}\right]$ pregnenolone by a homogenate of $150 \mathrm{mg}$ of tissue from Snell adrenocortical carcinoma 494 incubated for $90 \mathrm{~min}$

\author{
Steroid investigated and \\ derivative formed
}

Pregnenolone

20 $\beta$-Hydroxypregnenolone

Pregnenolone

Progesterone

20 $\beta$-Hydroxyprogesterone

$20 \beta$-Acetoxyprogesterone

Deoxycorticosterone

Deoxycorticosterone acetate

20ß,21-Dihydroxypregn-4-en-3-one

Corticosterone

Corticosterone acetate

$11 \beta, 20 \beta, 21$-Trihydroxypregn-4-en-3-one
Final

solvent system

\section{IV}

IV

$\mathbf{X}$

I

IV

I

IV

I

V

V

IV

XI
Specific

radioactivities

(d.p.m./nmol)

\begin{tabular}{|c|c|}
\hline $\begin{array}{c}\text { Rat adrenal } \\
\text { tissue }\end{array}$ & $\begin{array}{c}\text { Snell } \\
\text { carcinoma } \\
494\end{array}$ \\
\hline $\begin{array}{l}18.7 \\
17.9\end{array}$ & $\begin{array}{l}7880 \\
7804\end{array}$ \\
\hline 18.5 & 8176 \\
\hline 6.4 & 859 \\
\hline 6.1 & 845 \\
\hline 6.0 & 822 \\
\hline 5.8 & 8421 \\
\hline 5.6 & 8632 \\
\hline 5.9 & 8384 \\
\hline 1844 & 635 \\
\hline 1808 & 670 \\
\hline 1797 & 622 \\
\hline
\end{tabular}

$\%$ of radioactivity

found in isolated steroids
Ratadrenal carcinoma tissue $\quad 494$

0.6

0.2

0.2

43.1

50.7

3.1

Vol. 126 
Table 4. Conversion of $10 \mu \mathrm{Ci}$ of $\left[7 \alpha_{-}{ }^{3} \mathrm{H}\right]$ dehydroepiandrosterone into $C_{19}$-steroid metabolites by homogenates of $50 \mathrm{mg}$ of adrenal tissue from female LACA and NH mice incubated for $90 \mathrm{~min}$

— indicates that the steroid was not examined.

Steroid investigated and derivative formed
Final

solvent system

I

IV

Androst-5-ene-3 $\beta, 17 \beta$-diol

Dehydroepiandrosterone acetate

Androstenedione

Testosterone

Testosterone acetate

Testosterone

Androstenedione

Testosterone acetate

$5 \alpha$-Androstanedione

$5 \alpha$-Androstane-3 $\beta, 17 \beta$-diol

$5 \alpha$-Androstane-3 $\beta, 17 \beta$-diol diacetate

Androsterone

Androsterone acetate

$5 \alpha$-Androstanedione

Epiandrosterone

Epiandrosterone acetate

$5 \alpha$-Androstanedione

$5 \alpha$-Dihydrotestosterone

$5 \alpha$-Androstanedione

$5 \alpha$-Androstane- $3 \beta, 17 \beta$-diol

$5 \alpha$-Androstane-3 $\alpha, 17 \beta$-diol

$5 \alpha$-Androstanedione

$5 \alpha$-Androstane-3 $\beta, 17 \beta$-diol diacetate

$5 \alpha$-Androstane-3 $\beta, 17 \beta$-diol

$5 \alpha$-Androstanedione

$5 \alpha$-Androstane-3 $\beta, 17 \beta$-diol diacetate

$5 \beta$-Androstanedione

$5 \beta$-Androstane- $3 \alpha, 17 \beta$-diol

$5 \beta$-Androstane- $3 \alpha, 17 \beta$-diol diacetate

Aetiocholanolone

Aetiocholanolone acetate

$5 \beta$-Androstanedione

Epiaetiocholanolone

Epiaetiocholanolone acetate

$5 \beta$-Androstanedione

$5 \beta$-Dihydrotestosterone

$5 \beta$-Androstanedione

$5 \beta$-Androstane-3 $\alpha, 17 \beta$-diol

$11 \beta$-Hydroxyandrostenedione $11 \beta$-Hydroxytestosterone

Adrenosterone
VII

I

IV

I

IV

I

I

II

VI

III

I

VII

II

I

VII

II

IV

II

VI

VI

II

III

VI

II

III

II

IX

III

IV

VII

II

IV

VII

II

IV

II

IX

IV

V

IV
Specific

radioactivities

(d.p.m./nmol)

$\overbrace{\begin{array}{c}\text { LACA-mouse } \\ \text { adrenal tissue }\end{array}}^{\begin{array}{c}\text { NH-mouse } \\ \text { adrenal tissue }\end{array}}$

42.5

39.1

40.9

45.1

45.9

41.9

5.6

5.9

5.6

80.0

74.3

74.2

273

288

277

189

196

193

50.9

49.5

52.7

169

169

174

146

137

146

76.3

75.2

70.9

5823

6165

6176

53.4

54.0

52.2

78.2

86.7

80.6

3275

3056

3023

$\left.\begin{array}{rl}161 \\ 173 \\ 171 \\ 3252 \\ 3101 \\ 3331 \\ 374 \\ 370 \\ 378 \\ 140 \\ 144 \\ 144\end{array}\right\}$

531

502

483

469

471

475

32.5

29.9

32.5

27.5

28.6

28.1

58.4

59.7

57.7

2957

3025

2902

1649

1690

1681

2238

2240

2405

191

193

179

628

673

694
1.15

0.19

0.96

0.39

0.50

20.0

$\%$ of radioactivity found in isolated steroids

LACA-mouse NH-mouse

adrenal tissue adrenal tissue

0.28

22.0

41.1

11.4

0.36

15.6

0.56

20.2

4.20 
Table 4 (continued)

\begin{tabular}{|c|c|c|c|c|c|}
\hline $11 \beta$-Hydroxyandrosterone & V & 40.2 & & & \\
\hline $\begin{array}{l}11 \beta \text {-Hydroxyandrosterone } \\
\text { acetate }\end{array}$ & IV & 43.6 & - & 0.27 & - \\
\hline $5 \alpha$-Androstane-3,11,17-trione & VIII & 40.8 & & & \\
\hline $11 \beta$-Hydroxyepiandrosterone & V & 247 & & & \\
\hline $\begin{array}{l}11 \beta \text {-Hydroxyepiandrosterone } \\
\text { acetate }\end{array}$ & IV & 270 & - & 1.69 & \\
\hline $5 \alpha$-Androstane-3,11,17-trione & VIII & 262 & & & \\
\hline $11 \beta$-Hydroxyaetiocholanolone & V & 126 & & & \\
\hline $\begin{array}{l}11 \beta \text {-Hydroxyaetiocholanolone } \\
5 \beta \text {-Androstane-3,11,17-trione }\end{array}$ & $\begin{array}{l}\text { IV } \\
\text { VIII }\end{array}$ & $\begin{array}{l}135 \\
124\end{array}$ & - & 0.83 & - \\
\hline
\end{tabular}

metabolites, but the compounds formed were identical with those produced by adrenal tissue from LACA mice.

\section{Discussion}

Although the spatial integrity of the cell is destroyed in homogenized tissue, such a preparation was used in these investigations so that comparative studies could be readily undertaken. Further, it is recognized that the cofactor medium included a system for the maintenance of a high concentration of NADPH that is different from the physiological state. Under these conditions the conversion of $\left[7 \alpha^{-3} \mathrm{H}\right]$ cholesterol, but not $\left[4-{ }^{14} \mathrm{C}\right]$ pregnenolone, into $\mathrm{C}_{19}$-steroids by rat adrenal tissue (Table 1) supports the evidence of Jungmann (1968) for the existence of a pathway for dehydroepiandrosterone production from cholesterol without pregnenolone as an intermediate. However, the results of Burstein et al. (1971) caused them to conclude that pregnenolone was important in the biosynthesis of all rat adrenal steroid hormones. Throughout these studies, extremely low conversions were obtained for certain steroids. The biological significance of these values must be uncertain, but the constancy of the specific radioactivities of steroid and derivatives was taken as a further indication of the presence of the compounds in question.

The metabolites of $\left[7 \alpha-{ }^{3} \mathrm{H}\right]$ dehydroepiandrosterone produced by rat adrenal tissue under the conditions used in the present studies were principally ring-A-reduced compounds of the $5 \alpha$-series (Table 2). With the exception of $11 \beta$-hydroxyandrostenedione $(5.1 \%)$ only small amounts of $\Delta^{4}$-3-oxo steroids were detected $(<0.2 \%)$. Similarly production of $11 \beta$ hydroxylated steroids was very small (approx. 10\% of all metabolites investigated) but $3 \alpha-$ and $3 \beta-$ hydroxy steroid dehydrogenases were both highly active, over $50 \%$ of the radioactivity being associated with androsterone, epiandrosterone and their $11 \beta$ hydroxylated derivatives.
No significant difference in the activities of steroid-metabolizing enzymes was detected between strains, sexes or ages (up to 15 months) in rats of the Sprague-Dawley, Wistar or Osborne-Mendel strains. However, tissue from the transplantable adrenocortical tumour 494, which arose originally in a female Osborne-Mendel rat (Snell \& Stewart, 1959) showed a greatly decreased capacity for $5 \alpha$-reduction as $68.0 \%$ of the radioactivity was associated with androstenedione. Pregnenolone metabolism was also greatly decreased (Table 3) owing to a markedly low $11 \beta$-hydroxylase activity, a finding consistent with previous reports (Johnson et al., 1961; Sweat \& Bryson, 1964).

In contrast with the situation found in the strains of rats examined, there were substantial differences in the proportions of the metabolites produced by adrenal tissue from female NH-strain mice, to that produced by adrenal tissue from female LACAstrain mice. These differences are particularly noticeable in the ratio of $3 \alpha$ - to $3 \beta$-hydroxylated steroids. Thus approximately equal quantities of aetiocholanolone and epiaetiocholanolone were produced by $\mathrm{NH}$ mouse adrenal tissue, but very little epiaetiocholanolone by adrenal tissue from LACA mice (Table 4). The metabolism of androstenedione was also different, $22 \%$ of the radioactivity being associated with this steroid in the NH mouse adrenal incubation in contrast with $0.5 \%$ in the incubation with LACA mouse adrenal tissue. Further evidence is necessary to assess the significance of these differences, in particular of their relationship to the development of adrenocortical neoplasia.

We gratefully acknowledge the generous financial support of the Tenovus Organization in Cardiff. We also thank Dr. Katharine C. Snell, National Cancer Institute, Bethesda, Md., U.S.A., for the gift of the transplantable adrenocortical tumour, Professor Lucio Severi, Istituto di Anatomia e Istc! scia Patologica, University of Perugia, Perugia, Italy and Mr. Samuel M. Poiley, National Cancer Institute, Bethesda, for the original OsborneMendel rats, and Dr. Annabel Liebelt, Department of 
Anatomy, Baylor University, Houston, Tex., U.S.A., for the original NH mice. Dr. Marion K. Birmingham, Allen Memorial Institute of Psychiatry, McGill University, Montreal, Que., Canada, and Dr. Keith Griffiths, Tenovus Institute for Cancer Research, Welsh National School of Medicine, Cardiff, greatly assisted us with constructive criticism and advice.

\section{References}

Burstein, S., Zamoscianyk, H., Co, N., Adelson, M., Prasad, D. S. M., Greenberg, A. \& Gut, M. (1971) Biochim. Biophys. Acta 231, 223

Favino, A., Baillie, A. H. \& Griffiths, K. (1966) J. Endocrinol. 35, 185

Griffiths, K. \& Glick, D. (1966) J. Endocrinol. 35, 1
Griffiths, K., Grant, J. K. \& Whyte, W. G. (1963) J. Clin. Endocrinol. Metab. 23, 1044

Johnson, D. F., Snell, K. C., Francois, D. \& Heftmann, E. (1961) Acta Endocrinol. (Copenhagen) 37, 329

Jungmann, R. A. (1968) Biochim. Biophys. Acta 164, 110

Kirschbaum, A., Frantz, M. \& Williams, W. L. (1946) Cancer Res. 6, 707

Kornberg, A. \& Horecker, B. L. (1955) Methods Enzymol. 1,323

Okita, G. T., Kabara, J. J., Richardson, F. \& LeRoy, G. V. (1957) Nucleonics 13,111

Pierrepoint, C. G., Anderson, A. B. M., Griffiths, K. \& Turnbull, A. C. (1969) Res. Vet. Sci. 10, 477

Snell, K. C. \& Stewart, H. L. (1959) J. Nat. Cancer Inst. 22, 1119

Sweat, M. L. \& Bryson, M. J. (1964) J. Nat. Cancer Inst. 33,849 